\title{
New Development of Natural Depigmentation Agent from Anemarrhena asphodeloides Root Extracts by Inhibition of Melanin Biosynthesis
}

\author{
Soo-Kyung Seo ${ }^{1}$, Seong-Jeong Han ${ }^{1}$, Chang-Sub Ku ${ }^{1}$, Dae-Hyun Kim ${ }^{1}$, Ja-Hyun Ryu ${ }^{2}$, Ji-Hwoon Baek ${ }^{2}$, Jae-Sook Koh ${ }^{2}$, Dong-II Jang ${ }^{1 *}$ \\ ${ }^{1}$ Cosmeceutical Science Institute, COTDE Inc., Cheonan-si, Chungcheongnam-do, Korea \\ ${ }^{2}$ Dermapro Skin Research Center, DERMAPRO Ltd., Seoul, Korea
}

\author{
*Corresponding author: Dong-II Jang, \\ Cosmeceutical Science Institute, COTDE Inc., \\ 19-3 Ugakgol-gil, Susin-myeon, Dongnam-gu, \\ Cheonan-si, Chungcheongnam-do 31252, Korea \\ Tel.: +82415561364 \\ Fax: +82 415871376 \\ Email: daniel@cotde.co.kr
}

Received April 4, 2017

Revised October 26, 2017

Accepted November 13, 2017

Published March 30, 2018

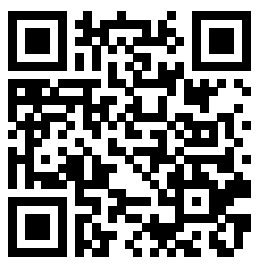

\begin{abstract}
Purpose: This study aimed to confirm the depigmentation effects from Anemarrhena asphodeloides root extracts (AARE). Methods: We assessed tyrosinase inhibition activity of AARE and investigated the biosynthesis of melanin in B16F10 melanoma cells and subjected to clinical trials with AARE creams. Results: Tyrosinase activity and melanin biosynthesis induced by $\alpha$-melanocyte stimulating hormone ( $\alpha-\mathrm{MSH}$ ) were inhibited by AARE in a concentration-dependent manner. In particular, at 25 $\mu \mathrm{g} / \mathrm{mL}$ concentration, melanin biosynthesis was more effectively inhibited by AARE (28.4\%) than arbutin (24.7\%; a well-known melanin synthesis inhibitor). In clinical trials, we investigated the changes in human skin brightness values over eight weeks using a cream formulation that contained $2 \%$ AARE after inducing pigmentation via ultraviolet irradiation. We showed that the hyperpigmentation degree, melanin index, and skin brightness were significantly improved. Conclusion: AARE is expected to become widely available as a functional cosmetic material for skin whitening.
\end{abstract}

Keywords: Anemarrhena asphodeloides, Tyrosinase, Natural depigmentation agent, Skin brightness, Melanin

\section{Introduction}

멜라닌(melanin)은 표피 기저층에 존재하는 멜라닌 세포 (melanocyte) 내의 멜라노좀(melanosome)이라고 하는 세포 소기관에서 생합성된다. 멜라닌은 멜라노좀에서 합성된 후 멜 라닌 세포의 수지상 돌기를 통해 각질형성세포(keratinocyte) 를 거쳐 결국에는 피부 각질층으로 이동한다(Gilchrest \& Eller, 1999; Taylor, 2002). 이러한 멜라닌의 생성은 외부환경 인 자외선 등으로부터 피부를 보호하는 중요한 피부 방어기작 중 하나이다(Uyen et al., 2008). 그러나 멜라닌이 과발현 되 면 피부 표면에 침착되어 주근깨, 기미, 피부반점 등의 색소침 착을 유발하고 동시에 피부의 생리기능이 떨어져 흑색종으로 발달되기도 한다(Hill et al., 1997; Park et al., 2015a).

오랫동안 자외선에 피부가 노출되면 멜라닌 생성 유도 인자 인 $\alpha-\mathrm{MSH}$ 이 각질세포에서 분비된다(Imokawa et al., 1997).
$\alpha-\mathrm{MSH}$ 이 자극원으로서 melanocortin 1 receptor (MC1R) 에 붙게 되면 세포 내에서 adenylate cyclase (AC)가 활성화되 면서 동시에 cyclic adenosine monophosphate (cAMP)의 농 도가 증가하여 protein kinase A (PKA)에 의해 tyrosinase 가 활성화 된다(Thody \& Graham, 1998). Tyrosinase는 아 미노산의 일종인 L-tyrosine에서 dopaquinone으로 전환되 는 과정에서 이를 촉진하는 중요한 효소이며, eumelanin과 pheomelanin의 합성에 모두 관여한다(Esposito et al., 2013; Ryu, 2011). 따라서 tyrosinase 활성을 억제하는 물질에 대한 연구가 미백 화장품 소재 개발 연구의 중요한 부분을 차지하고 있다(Kang et al., 2008).

현재까지 멜라닌 합성의 중요한 인자로 알려져 있는 tyrosinase를 억제하는 대표적인 물질로는 알부틴(arbutin), 코직산(kojic acid), 하이드로퀴논(hydroquinone), 비타민 C (vitamin C) 등이 있다. 특히 알부틴은 tyrosinase 활성 억 
제 기능과 더불어 5,6-dihydroxyindole-2-carboxylic acid (DHICA) polymerase 활성으로 인한 멜라노좀 생성 억제 효과 도 가지고 있다고 알려져 있다(Chakraborty et al., 1998). 하 지만 이들 물질들에 대한 안정성 및 안전성에 대한 문제점, 그 리고 부작용에 대한 연구들이 나오면서 계속해서 논란이 일어 나고 있다(Briganti et al., 2003; Solano et al., 2006). 따라 서 기존에 알려진 멜라닌 생성을 억제하는 소재들이 가지고 있 는 문제점들을 극복하고 보다 안전하고 우수한 효과를 갖는 소 재를 탐색하기 위하여 천연물 유래 소재들에 대한 연구가 활발 히 진행되고 있다.

지모(Anemarrhena asphodeloides)는 백합과(Liliaceae) 에 속하는 다년생 초본으로서 근경을 건조한 것을 주로 약재 로 사용한다. 지모의 뿌리는 약리학적 작용으로 소염작용, 진 정제, 이뇨제, 항당뇨, 항균, 항암작용의 효과를 가지고 있으며 주요 성분으로는 steroid saponin에 속하는 anemarsaponin B, smilageninoside, degalactotigonin, F-gitonin, timosaponin A-III 등이 있고, xanthone glycoside에 속하 는 mangiferin, isomangiferin, neomangiferin 등이 보고 되어 있다(Miura et al., 2001; Son et al., 1999; Sy et al., 2008; Tang et al., 2015; Wang et al., 2002). 또한, 최근 연구에 의하면 지모의 성분 중 하나인 니아졸(nyasol)은 항균 효과가 있다고 알려져 있다(Iida et al., 2000; Park et al., 2003). 한편, 최근 본 연구팀의 지모뿌리추출물(Anemarrhena asphodeloides root extracts, AARE)에 대한 연구에서, $\mathrm{AARE}$ 의 유효성분인 니아졸을 구조 동정하여 멜라닌 생합성 억제 및 tyrosinase 저해 활성을 측정함으로써 니아졸의 뛰어 난 미백 효과에 대하여 보고한 바 있다(Park et al., 2015b).

본 연구에서는 이를 바탕으로 정제 과정이 복잡하고 시간이 오래 걸리는 기존의 순수한 니아졸을 정제하는 방법이 아닌 에 탄올 추출법을 이용한 지모뿌리추출물을 이용하여 mushroom tyrosinase 활성 억제 평가 및 세포에 추출물을 처리하여 멜라 닌 생합성량의 변화를 측정하였고, 이 물질이 $2 \%$ 함유된 크림 제형을 제조하여 임상연구를 진행하였으며 천연 미백 화장품 소재로서의 활용 가능성을 검토하였다.

\section{Methods}

\section{1. 지모뿌리추출물의 제조}

제주도에서 자생한 지모뿌리를 현지에서 구매하여 $95 \%$ 에 탄올(Duksan Pure Chemicals, Korea) 12.5 L에 $5 \mathrm{~kg}$ 을 넣어 실온에서 14 일 동안 추출한 후, 여과지(Whatman ${ }^{\circledR}$ qualitative filter paper, Grade 2; GE Healthcare Life Sciences, USA) 로 여과하여 에탄올 추출물을 얻었다. 이 에탄올 추출물을 $65^{\circ} \mathrm{C}$ 에서 감압 농축하여 얻은 농축물(회수량: $223 \mathrm{~g}$ )에 정제수 $2.23 \mathrm{~kg}$ 을 넣고 교반한 후 물 가용부를 제거하고, 물 침전부에 $95 \%$ 에탄올을 넣고 교반한 후 여과하여 에탄올 가용부를 얻었 다. 이 에탄올 가용부를 $65^{\circ} \mathrm{C}$ 에서 감압농축 건조하여 갈색가 루 $20.6 \mathrm{~g}$ 을 회수하였다. 회수된 추출물은 세포배양실험에 사 용하기 위하여 dimethyl sulfoxide (DMSO; Sigma-Aldrich, USA)에 녹인 후 희석하여 세포에 처리하였다.

\section{2. 세포배양}

Melanoma cell line인 B16F10 cell은 한국세포주은행 (Korean Cell Line Bank, Korea)에서 구입하였으며, 세포 배 양을 위해 Dulbecco's Modified Eagles Medium (DMEM; HyClone $^{\mathrm{TM}}$, GE Healthcare Life Sciences)에 1\% AntibioticAntimycotic (AA; Gibco ${ }^{\circledR}$, Thermo Fisher Scientific, USA), $10 \%$ Fetal Bovine Serum (FBS; Gibco ${ }^{\circledR}$ )을 첨가하여 $37^{\circ} \mathrm{C}$, $5 \% \mathrm{CO}_{2}$ 배양기에서 배양하였다.

\section{3. 세포 생존율 측정}

B16F10 melanoma 세포의 생존율은 Mosmann (1983) 방 법으로 측정하였다. 살아있는 세포는 대사가 왕성하여 미토 콘드리아의 탈수소 효소작용이 일어나는데, 이 작용에 의하 여 노란색의 수용성인 3-(4,5-dimethyl-2-thiazolyl)-2,5diphenyl-2H-tetrazolium bromide (MTT; Sigma-Aldrich) 를 환원시켜 자주색의 비수용성인 formazan을 형성한다. $\mathrm{B} 16 \mathrm{~F} 10$ melanoma 세포를 $10 \% \mathrm{FBS}$ 가 첨가된 $\mathrm{DMEM}$ 배지를 이용하여 각각의 well 당 $0.5 \times 10^{4}$ cells/well의 밀도로 96 well plate $\left(\mathrm{Nunc}^{\mathrm{TM}}\right.$, Thermo Fisher Scientific)에 접종하여 $24 \mathrm{~h}$ 배양한 후에 $200 \mathrm{nM}$ 의 $\alpha-\mathrm{MSH}$ (Sigma-Aldrich)와 AARE 를 농도별로 배양액에 희석하여 세포에 처리한 후 $48 \mathrm{~h}$ 동안 배양하였다. 배양이 끝난 후 $2 \mathrm{mg} / \mathrm{mL}$ 농도의 MTT 용액을 $50 \mu \mathrm{L}$ 처리하고 $4 \mathrm{~h}$ 동안 $\mathrm{MTT}$ 가 환원되도록 반응시켰다. 반 응이 끝난 후 배양액을 제거하고 phosphate buffered saline $\left(\mathrm{PBS} ; \mathrm{Gibco}^{\circledR}\right)$ 로 세척한 후 $\mathrm{DMSO}$ 를 $200 \mu \mathrm{L}$ 를 가하여 생성된 formazan 결정을 완전히 용해시킨 후, $540 \mathrm{~nm}$ 에서 enzymelinked immunosorbent assay (ELISA) reader (Biochrom ${ }^{\circledR}$ Asys UVM340 Microplate Reader; Biochrom, UK)를 이용 하여 흡광도를 측정하였다. 각 시료군의 평균 흡광도 값을 구 하였고, $\alpha-\mathrm{MSH}$ 를 처리한 대조군의 흡광도 값을 대비로 세포 생존율을 평가하였으며 모든 실험은 3 회 반복 수행하였다.

\section{4. 멜라닌 생성 억제능 측정}

멜라닌 생성 억제능 측정은 식품의약품안전처에 고시되어있 는 기능성 화장품의 유효성평가 방법을 사용하였다(Ministry of Food and Drug Safety, 2003). B16F10 melanoma 세 
포를 $10 \% \mathrm{FBS}$ 가 첨가된 $\mathrm{DMEM}$ 배지를 이용하여 각각의 well 당 $0.5 \times 10^{5}$ cells/well의 밀도로 6 well plate ( $\mathrm{Nunc}^{\mathrm{TM}}$ ) 에 넣고 $24 \mathrm{~h}$ 배양한 후, $200 \mathrm{nM}$ 의 $\alpha-\mathrm{MSH}$ 와 AARE를 농 도별로 세포에 함께 처리한 후 $48 \mathrm{~h}$ 배양하였다. 배양 완료 후 상등액을 제거하고 세포를 PBS로 세척한 후에 trypsinethylenediaminetetraacetic acid (trypsin-EDTA; Gibco ${ }^{\circledR}$ ) 를 처리하여 세포를 회수하고 $1 \mathrm{~N}$ sodium hydroxide $(\mathrm{NaOH}$; Sigma-Aldrich)를 넣고 $60^{\circ} \mathrm{C}$ 항온조에서 용해시킨 후 원심분 리하여 용해된 상층액을 $490 \mathrm{~nm}$ 에서 흡광도를 측정하였다. 멜 라닌 생합성 저해는 $\alpha-\mathrm{MSH}$ 를 처리한 대조군과 비교하여 샘플 용액의 첨가군과 무첨가군의 흡광도 감소율을 백분율로 나타내 었으며 양성대조군으로 $25 \mu \mathrm{g} / \mathrm{mL}$ 농도의 알부틴을 사용하였 다.

\section{Tyrosinase 저해 활성 측정}

Tyrosinase 저해 활성은 Yagi et al., (1987) 방법으로 측정 하였다. 먼저 AARE와 양성대조군인 알부틴(Sigma-Aldrich) 을 최종농도가 $6.25,12.5,25 \mu \mathrm{g} / \mathrm{mL}$ 이 되도록 희석하여 시 료를 준비하였다. 반응구는 $0.175 \mathrm{M}$ sodium phosphate buffer (pH 6.8; Samchun Pure Chemical, Korea) $125 \mu \mathrm{L}$ 에 mushroom tyrosinase (110 U/mL; Sigma-Aldrich) $50 \mu$ $\mathrm{L}$ 및 시료용액 $25 \mu \mathrm{L}$ 를 혼합한 후 $10 \mathrm{mM} \mathrm{3,4-dihydroxy-}$ $\mathrm{L}$-phenylalanine (L-DOPA; Sigma-Aldrich) $50 \mu \mathrm{L}$ 를 첨가하여 $37^{\circ} \mathrm{C}$ 에서 $2 \mathrm{~min}$ 간 반응시킨다. 반응액 중에 생 성된 dopachrome을 $475 \mathrm{~nm}$ 에서 흡광도를 측정하였다. Tyrosinase 저해 활성은 시료용액의 첨가구와 무첨가구의 흡 광도 감소율로 나타내었으며 3 번 반복하여 수행하였다.

\section{6. 임상연구}

임상연구는 (주더마프로 피부임상연구센터(Dermapro Skin Research Center, Korea)와 공동으로 진행하였고, 시험기간은 8주 동안 진행하였다. 본 임상연구는 성인 남녀로 Fitzpatrick skin type (Fitzpatrick, 1975) 분류에 따라 광피부 타입이 III 또는 IV인 37-49세(평균나이 $41.95 \pm 3.85$ 세)의 여성 피험자 22 명을 대상으로 하였으며, $\mathrm{AARE}$ 의 피부 미백 효과를 알아 보기 위하여 (주더마프로에 의뢰하여 임상시험심사위원회 승인 (제1-220777-A-N-02호-DICN15025)을 거쳐서 임상시험을 실시하였다. 시험 시료는 $\mathrm{AARE}$ 를 $2 \%$ 함유하는 시험군(test group, A)과, AARE를 함유하지 않은 대조군(control group, $\mathrm{B})$ 을 크림 형태로 제조하여, 시험부위에 자외선으로 색소침착 을 유도한 후에 제품 $\mathrm{A}, \mathrm{B}$ 를 각각 시험부위에 사용하게 하였 다. 피험자는 block randomization을 통해 두 그룹으로 나누 어 시험 부위인 전박의 2 곳의 테스트 부위에 한 그룹은 위로부 터 제품을 $\mathrm{A}, \mathrm{B}$ 순으로, 다른 그룹은 위로부터 제품 $\mathrm{B}, \mathrm{A}$ 순으로
바르도록 하였다. 모든 피험자는 방문 시마다 시험부위를 세척 한 다음에 항온항습실 $\left(22 \pm 2{ }^{\circ} \mathrm{C}, 50 \pm 5 \%\right)$ 에 입실하였으며 20 $\min$ 동안 안정을 취한 후 시험에 참여하였다. 평가는 제품 사 용 전과 사용 후 각 시점 $(2,4,6,8$ 주)에서 과색소침착 부위의 육안평가, 멜라닌 지수 측정, 피부 밝기 등을 시험자의 관찰과 문진 및 기기를 이용하여 평가하였다.

1) 인공색소침착 유도

선정된 피험자의 전박 부위에 LS1000 Solar Simulator (Solar ${ }^{\circledR}$ Light, USA)를 이용하여 자외선(UVA+B) 조사 후 최 소 홍반량(minimal erythema dose; MED)을 결정하고 $\mathrm{MED}$ 의 2-4.5 배에 해당하는 자외선을 전박 2 부위에 조사하여 인공 적으로 색소침착을 유발시켰다.

\section{2) 과색소침착 부위의 육안평가}

육안평가는 각 평가시점에서 2 명의 시험자가 시험부위의 과 색소침착 정도를 0-9단계의 10 점 척도 $(0$, 밝고 투명함; 9 , 어 둡고 칙칙함)의 기준으로 독립적으로 평가하였으며, 시험자 간 intraclass correlation coefficient (ICC) value가 0.8 이상이 면 시험자 간의 신뢰도를 인정하여 평균값을 적용하여 분석하 였다.

\section{3) 기기를 이용한 멜라닌 지수 및 피부 밝기 측정}

멜라닌 지수 측정은 Mexameter ${ }^{\circledR} \mathrm{MX} 18$ (Courage+ Khazaka electronic, Germany)를 이용하였다. 이는 피부색 을 결정하는 주요 요인인 멜라닌과 헤모글로빈의 양을 흡광 원 리를 이용하여 측정하는 장치로서 각 파장 영역의 피부 흡수 율을 디지털화하여 멜라닌 지수(melanin index)와 홍반 지수 (erythema index)로 표시해 준다. 본 시험은 각 평가시험에서 과색소침착 부위를 3 회 측정한 후 멜라닌 지수의 평균값을 분 석하였다. 피부색 측정은 spectrophotometer (CM-2500d; Konica Minolta, Japan)를 이용하였다. 이는 물체색의 분광반 사율을 측정하는 장비로서 삼색 자극값(tristimulus value)을 측정하여 피부의 밝기 및 채도를 계산해준다. 본 시험은 각 평 가시점에서 과색소침착 부위를 3 회 측정한 후 평균값을 이용하 여 피부 밝기(luminance parameters, $\mathrm{L}^{*}$ value)를 분석하였 다.

\section{7. 통계처리}

모든 실험결과는 Statistical Package for the Social Sciences (SPSS; IBM, USA) 프로그램을 이용하여 데이터 통 계를 분석하였다. AARE에 의한 tyrosinase assay, 세포 생존 율 그리고 멜라닌 생합성에 관한 모든 실험은 3회 반복 수행되 었고 평균 \pm 표준편차(mean \pm standard deviation, $\mathrm{M} \pm \mathrm{SD}$ )로 


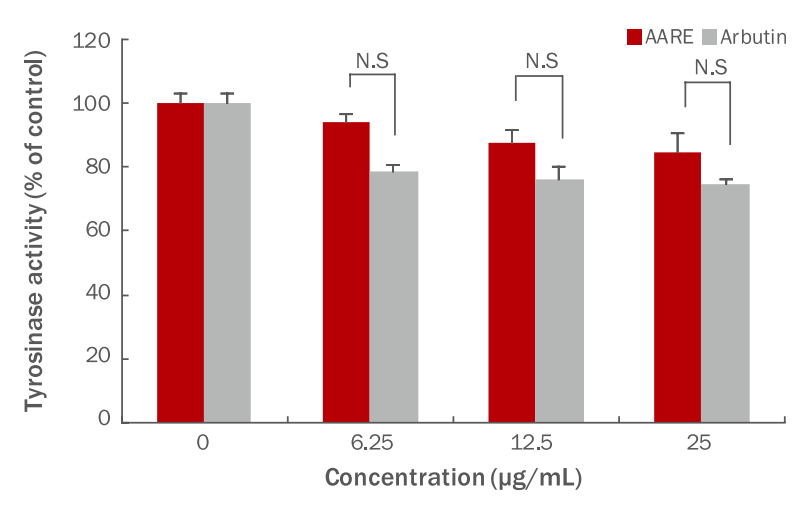

Figure 1. Effects of AARE on mushroom tyrosinase activity. Mushroom tyrosinase $(110 \mathrm{U} / \mathrm{mL})$ was mixed with various AARE concentrations and incubated with L-DOPA (10 $\mathrm{mM}$ ) for $2 \mathrm{~min}$ at $37^{\circ} \mathrm{C}$. Tyrosinase activities of both AARE and arbutin were decreased in a dose-dependent manner. Higher tyrosinase inhibition was observed with arbutin than AARE. The results are expressed as the average of percentages in triplicate samples. Arbutin was used as the positive control. The values are $\mathrm{M} \pm \mathrm{SD}$ of three independent experiments. AARE, Anemarrhena asphodeloides root extracts; L-DOPA, 3,4-dihydroxy-Lphenylalanine; $\mathrm{M} \pm \mathrm{SD}$, mean \pm standard deviation; N.S, not significant.

표기하였으며 각 샘플마다 3 번씩 반복 측정한 평균값에 반복측 정 분산분석법(repeated measures analysis of variance, $\mathrm{RM}$ ANOVA)을 적용하였다. 임상연구 데이터는 평균표준오차 (mean \pm standard error of measurement, $\mathrm{M} \pm \mathrm{SEM}$ )로 표기 하였으며, 자료 분석을 위한 정규성 및 사전 동질성은 paired $t$-test를 통해 검증하였고, 동일 피험자의 상호의존성, 군간 비교 및 전후 시점별 변화 확인은 반복측정 분산분석법( $\mathrm{RM}$ ANOVA)을 이용하여 분석하였으며, 모든 데이터의 통계학적 유의수준은 $p<0.05$ 값을 유의성 있는 것으로 설정하였다.

\section{Results and Discussion}

\section{Tyrosinase 저해 활성 측정}

Tyrosinase는 생체 내 멜라닌 합성기작에서 tyrosine이 $\mathrm{DOPA}$ 및 dopaquinone으로 산화되며 전환되는 과정 중에 필 요한 중요한 효소이다. 대부분의 피부 미백에 대한 연구는 이 효소를 억제하는 물질에 대한 연구가 많이 진행되고 있다. 이 번 연구에서는 $\mathrm{AARE}$ 에 의한 tyrosinase 저해 활성을 측정하 기 위하여 양성대조군으로 알부틴을 처리한 시험군과 함께 흡 광도를 측정하였다. 그 결과 $\mathrm{AARE}$ 는 tyrosinase 활성을 $25 \mu$ $\mathrm{g} / \mathrm{mL}$ 의 농도에서 $15.5 \%$ 의 저해율을 나타냈고, 같은 농도에 서 양성대조군인 알부틴은 $25.2 \%$ 의 저해율을 나타내었다. 비 록 $\mathrm{AARE}$ 는 대조군인 알부틴에 비하여 tyrosinase 억제 효과

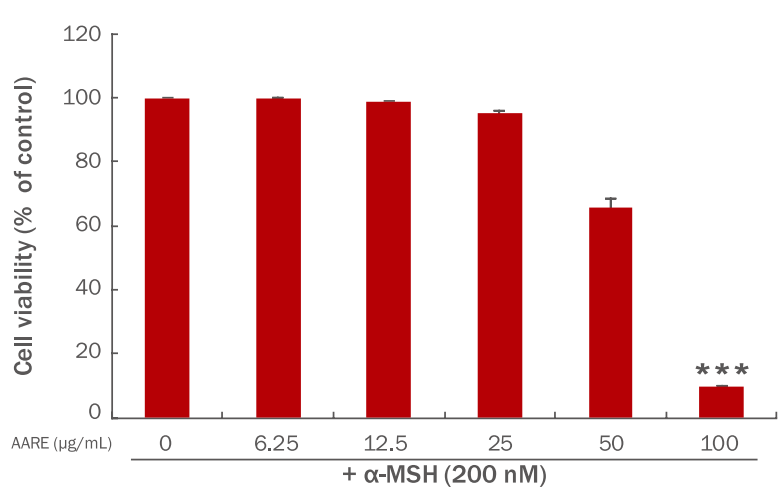

Figure 2. Cell viability of AARE on B16F10 melanoma cells. Cell viability was examined the using by MTT assay. Cells were incubated with $200 \mathrm{nM} \alpha-\mathrm{MSH}$ and various AARE concentrations $(0-100 \mu \mathrm{g} / \mathrm{mL})$ for $48 \mathrm{~h}$. More than $95 \%$ of the cell were viable at concentrations of $<25 \mu \mathrm{g} / \mathrm{mL}$. The results are expressed as the average of percentages in triplicate samples. The values are given as $\mathrm{M} \pm \mathrm{SD}$ of three independent experiments. AARE, Anemarrhena asphodeloides root extracts; $\alpha$-MSH, $\alpha$-melanocyte stimulating hormone; MTT, 3-(4,5-dimethyl-2-thiazolyl)-2,5diphenyl-2H-tetrazolium bromide; $\mathrm{M} \pm \mathrm{SD}$, mean \pm standard deviation; ${ }^{* * *} p<0.001$ vs. AARE non-treated sample.

가 낮았지만, 농도 의존적으로 tyrosinase 활성을 저해하는 것 을 확인하였다(Figure 1).

\section{2. 멜라닌 생성 억제능 측정}

1) 세포 생존율 측정

$\mathrm{B} 16 \mathrm{~F} 10$ melanoma 세포에서의 AARE에 대한 세포 생존율 을 측정하였다. $\mathrm{AARE}$ 를 세포에 처리한 농도는 $0,6.25,12.5$, $25,50,100 \mu \mathrm{g} / \mathrm{mL}$ 이었다. 실험 결과는 대조군의 세포 생존율 을 $100 \%$ 로 설정하고 대조군 대비로 계산하여 상대적인 퍼센트 로 나타내었다. 그 결과 $\mathrm{AARE}$ 는 $50 \mu \mathrm{g} / \mathrm{mL}$ 에서 $65.6 \%, 25 \mu$ $\mathrm{g} / \mathrm{mL}$ 에서 $95.0 \%$ 의 세포 생존율을 나타내었다(Figure 2). 따 라서 AARE는 $25 \mu \mathrm{g} / \mathrm{mL}$ 이하의 농도에서 세포 생존율에 영향 을 미치지 않는 것을 확인할 수 있었으며 모든 실험은 $25 \mu \mathrm{g} /$ $\mathrm{mL}$ 이내의 구간에서 수행하였다.

\section{2) 멜라닌 생합성 저해 활성 측정}

$\mathrm{AARE}$ 에 대하여 미백 효과를 확인하기 위해 B16F10 melanoma 세포를 이용하여 세포 내에서 $\alpha-\mathrm{MSH}$ 에 의하여 유 도되는 멜라닌 생성량을 측정하여 비교하였다. $\alpha-\mathrm{MSH}$ 는 세 포 내에서 tyrosinase의 활성을 높여주어 멜라닌의 합성을 촉 진하게 된다. 각각의 농도별 $(0,6.25,12.5,25 \mu \mathrm{g} / \mathrm{mL}) \mathrm{AARE}$ 와 함께 $200 \mathrm{nM}$ 의 $\alpha-\mathrm{MSH}$ 를 세포에 처리하여 $48 \mathrm{~h}$ 배양 후 멜라닌 양을 측정하였다. 양성대조군으로 알부틴 $25 \mu \mathrm{g} / \mathrm{mL}$ 을 처리한 시험군과 비교하였다. 그 결과 $\mathrm{AARE}$ 가 농도 의존적으 


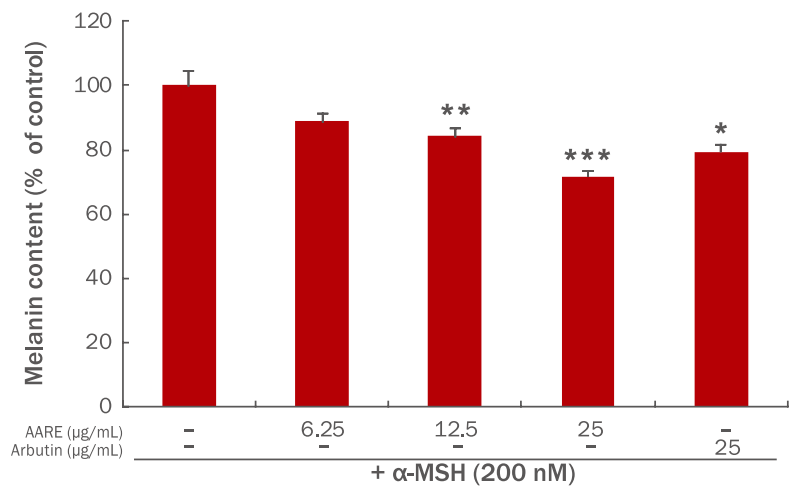

Figure 3. Inhibition of melanin synthesis in B16F10 melanoma cells by AARE treatment.

The effects of AARE on the inhibition of melanin synthesis were confirmed in B16F10 melanoma cells. The cells were incubated with various concentrations of AARE with $\alpha-\mathrm{MSH}$ $(200 \mathrm{nM})$ for $48 \mathrm{~h}$. Arbutin $(25 \mu \mathrm{g} / \mathrm{mL})$ was used as the positive control. Cells were lysed with $1 \mathrm{~N} \mathrm{NaOH}$ and then absorbance was measured at $490 \mathrm{~nm}$. The values are $M \pm S D$ of three independent experiments. Melanin content was decreased in a dose-dependent manner. In particular, the inhibitory effects of $25 \mu \mathrm{g} / \mathrm{mL}$ AARE on melanin synthesis were better than those of arbutin. AARE, Anemarrhena asphodeloides root extracts; $\alpha-\mathrm{MSH}, \alpha$-melanocyte stimulating hormone; $\mathrm{NaOH}$, sodium hydroxide; $\mathrm{M} \pm \mathrm{SD}$, mean \pm standard deviation; ${ }^{*} p<0.05,{ }^{* *} p<0.01$, ${ }^{* * *} p<0.001$ vs. AARE non-treated sample.

로 멜라닌의 합성을 억제하는 것을 확인하였다. $\mathrm{AARE}$ 에 대한 최고 유효 농도인 $25 \mu \mathrm{g} / \mathrm{mL}$ 에서 멜라닌 합성이 $28.4 \%$ 저해되 었고, 양성대조군인 알부틴은 $25 \mu \mathrm{g} / \mathrm{mL}$ 에서 $24.7 \%$ 저해되어 AARE는 알부틴보다 $3.7 \%$ 향상된 멜라닌 생합성 저해 효과를 확인할 수 있었다(Figure 3 ).

\section{3. 임상연구 결과}

$\mathrm{AARE} 2 \%$ 가 함유되어 있는 크림 성상의 제품을 제조하여 8 주 동안 여성 피험자 22 명을 대상으로 인공적으로 과색소침착 을 유도한 후 제품에 대한 피부 미백 효과를 평가하였다. 모든 임상연구는 (주더마프로에 의뢰하여 시험평가를 수행하였다.

\section{1) 과색소침착 부위의 육안평가 분석}

과색소침착 부위의 육안평가 분석 결과, 군간 비교 시 제품 사용 6주, 8 주 후 시점에서 시험군이 대조군에 비해 과색소침 착 정도가 유의하게 개선되었다 $(p<0.05)$. 제품 사용 전과 비교 시 두 군 모두 제품 사용 2 주 후 시점부터 과색소침착 정도가 유의하게 개선되었다. 8주 경과 후 control group (AARE가 함 유되지 않은 제품, $37.45 \%$ )에 비하여 test group (AARE 가 함 유되어 있는 제품, $41.09 \%)$ 에서 과색소침착 정도가 유의하게 감소되었다( $p<0.05$; Figure 4$)$.

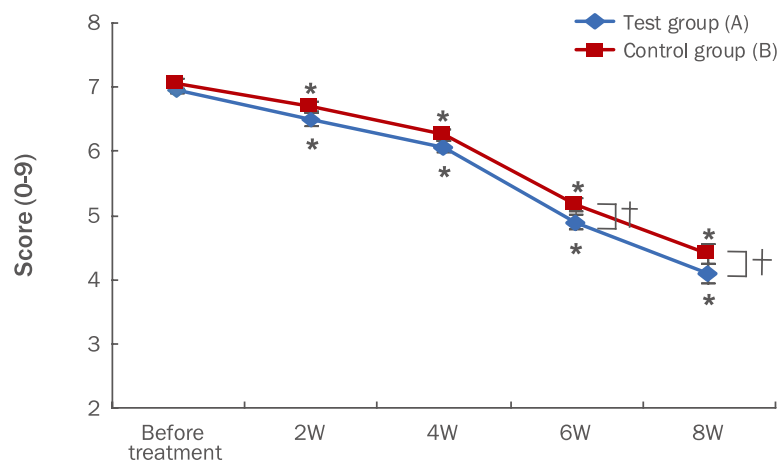

Figure 4. Changes in visual assessment following eight consecutive weeks application of the products.

Skin brightness was assessed by visual scoring (0-9) every two weeks for eight weeks after induction of pigmentation via UV irradiation. Depigmentation effects improved following AARE cream treatment. The results were expressed as $\mathrm{M} \pm \mathrm{SEM}$. Test group (A), treatment with cream containing of AARE; Control group (B), treatment with cream non-containing AARE; W, week; UV, ultraviolet; AARE, Anemarrhena asphodeloides root extracts; $\mathrm{M} \pm \mathrm{SEM}$, mean \pm standard error of measurement; " $p<0.05$ vs. before treatment; ${ }^{\dagger} p<0.05$ vs. test group and control group.

2) 흡광 원리를 이용한 멜라닌 지수 분석

멜라닌 지수 분석 결과, 제품 사용 8주 후 시점에서 시험군이 대조군에 비해 멜라닌 지수가 유의하게 낮았다( $\mathrm{p}\langle 0.05)$. 제품 사용 전과 비교 시 두 군 모두 제품 사용 2주 후 시점부터 멜라 닌 지수가 유의하게 개선되었으며 분석 결과 제품 사용 8 주 후 시점에서 제품 사용 전후를 비교한 결과 test group (16.47\%) 이 control group (13.72\%)에 비하여 유의하게 감소하였다 $(p<0.05$; Figure 5).

\section{3) 분광반사율을 이용한 피부 밝기 분석}

피부 밝기 분석 결과, 군간 비교 시 두 군 모두 제품 사용 2 주 후 시점부터 피부 밝기 $\left(\mathrm{L}^{*}\right.$ value $)$ 가 유의하게 개선되었다 $(p<0.05)$. 제품 사용 전과 비교 시 두 군 모두 제품 사용 2 주 후 시점부터 피부 밝기가 유의하게 개선되었으며 8주 후 시점에서 control group (4.44\%)에 비하여 test group (5.30\%)에서 피 부 밝기가 유의하게 증가하였다 $(p<0.05 ;$ Figure 6$)$. 


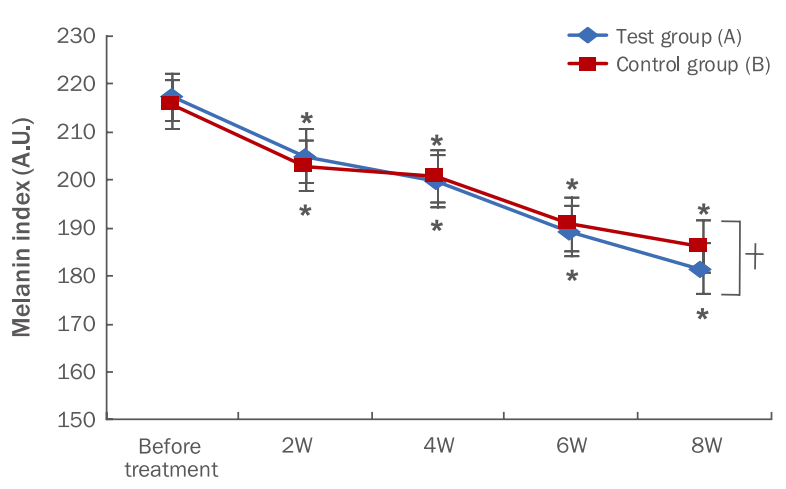

Figure 5. Changes in melanin index following eight consecutive weeks application of the products.

Melanin index was measured using Mexameter ${ }^{\circledR}$ MX 18 instrument. After 8 weeks, depigmentation effects were improved following AARE cream treatment. The results were expressed as $M \pm S E M$. Test group $(A)$, treatment with cream containing of AARE; Control group (B), treatment with cream non-containing AARE; W, week; AARE, Anemarrhena asphodeloides root extracts; $\mathrm{M} \pm \mathrm{SEM}$, mean \pm standard error of measurement; ${ }^{*} p<0.05$ vs. before treatment; ${ }^{\dagger} p<0.05$ vs. test group and control group.

\section{Conclusion}

본 연구에서는 $\mathrm{AARE}$ 에 대한 미백 화장품 원료로의 활 용 가능성을 확인하기 위해 tyrosinase 저해 활성과 B $16 \mathrm{~F} 10$ melanoma 세포를 이용하여 멜라닌 생합성 저해 활성을 측정하 였다. 이전의 연구 결과에서는 지모뿌리로부터 분획한 유효성분 인 니아졸이 피부 미백에 유용한 효과를 보여주었지만 상업적으 로 활용하기 위해서 많은 과정을 거쳐야 하는 한계점이 있어서 이번 연구에서는 $\mathrm{AARE}$ 로부터 직접적인 미백 효과를 연구하였 으며 추출한 소재를 이용한 $\mathrm{AARE} 2 \%$ 가 함유되어 있는 크림을 제작하여 임상연구를 수행하였다.

$\mathrm{AARE}$ 에 대한 tyrosinase 저해 활성을 측정한 결과 $25 \mu$ $\mathrm{g} / \mathrm{mL}$ 의 농도에서 $\mathrm{AARE}$ 와 알부틴의 tyrosinase 저해율 은 각각 $15.5 \%, 25.2 \%$ 를 나타내었다. 따라서 $\mathrm{AARE}$ 에 의한 tyrosinase 저해 활성 효과는 알부틴 보다 낮지만 농도 의존적 으로 tyrosinase 활성을 억제함으로써 효과가 있음을 알 수 있 었다. AARE에 대하여 세포독성이 없는 농도 범위 내에서 멜라 닌 생합성 억제 활성을 측정하기 위하여 세포 생존율을 측정하 였다. B16F10 melanoma cell을 이용하여 세포 생존율 측정 결 과 $25 \mu \mathrm{g} / \mathrm{mL}$ 이하의 농도에서 세포독성이 없는 것을 확인한 후 에 $200 \mathrm{nM} \alpha-\mathrm{MSH}$ 와 함께 $\mathrm{AARE}$ 를 세포독성이 없는 구간 내 에서 농도별로 세포에 처리하여 멜라닌 생합성 억제 활성을 측 정하였다. 그 결과, 멜라닌 생합성을 농도 의존적으로 억제함 을 확인하였다. $25 \mu \mathrm{g} / \mathrm{mL}$ 의 농도에서 AARE와 알부틴의 멜라

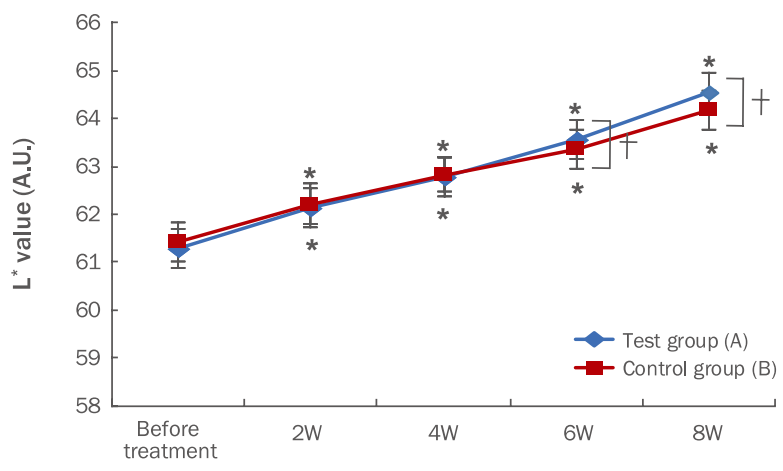

Figure 6. Changes in skin brightness following eight consecutive weeks application of the products.

Skin brightness was measured using a spectrophotometer (CM-2500d) instrument. After eight weeks, the luminance parameters ( $L^{*}$ value) in the test group significantly improved compared with those in the control group. The results were expressed as $\mathrm{M} \pm \mathrm{SEM}$. Test group (A), treatment with cream containing of AARE; Control group (B), treatment with cream non-containing AARE; W, week; AARE, Anemarrhena asphodeloides root extracts; $\mathrm{M} \pm \mathrm{SEM}$, mean \pm standard error of measurement; ${ }^{*} p<0.05$ vs. before treatment; ${ }^{\dagger} p<0.05$ vs. test group and control group.

닌 생합성 억제율은 각각 $28.4 \%, 24.7 \%$ 를 나타내었다. 따라서 $\mathrm{AARE}$ 의 효과가 $25 \mu \mathrm{g} / \mathrm{mL}$ 의 세포독성을 나타내지 않는 농도 구간에서 양성대조군인 알부틴 보다 멜라닌 생합성 저해 효과가 우수하다는 것을 확인하였다.

한편, AARE에 대하여 임상연구를 통한 미백 효과를 확인하 기 위하여 피험자에게 인공 색소침착을 유도한 다음 $\mathrm{AARE}$ 를 함유한 크림 제품을 8주 동안 사용하도록 한 후 결과를 분석하 였다. 그 결과 과색소침착 정도, 멜라닌 지수, 피부 밝기가 대조 군에 비하여 모두 유의하게 개선되었음을 확인하였다. 따라서, $\mathrm{AARE}$ 가 tyrosinase 활성 억제 및 melanin 생합성 저해를 통한 미백 기능성 천연 소재로서의 활용 가능성이 있는 것으로 사료 된다.

\section{Acknowledgements}

본 연구는 산업통상자원부 경제협력권산업육성사업에 의하여 이루어진 것임(과제고유번호 R0003963).

\section{References}

Briganti S, Camera E, Picardo M. Chemical and instrumental approaches to treat hyperpigmentation. Pigment Cell \& Melanoma Research, 16: 101-110, 2003.

Chakraborty AK, Funasaka Y, Komoto M, Ichihashi M. Effect of 
arbutin on melanogenic proteins in human melanocytes. Pigment Cell \& Melanoma Research, 11: 206-212, 1998.

Esposito D, Munafo JP Jr, Lucibello T, Baldeon M, Komarnytsky S, Gianfagna TJ. Steroidal glycosides from the bulbs of Easter lily (Lilium longiflorum Thunb.) promote dermal fibroblast migration in vitro. Journal of Ethnopharmacology, 148: 433440, 2013.

Fitzpatrick TB. Soleil et peau. Journal de Médecine Esthétique, 2: 33-34, 1975.

Gilchrest BA, Eller MS. DNA photodamage stimulates melanogenesis and other photoprotective responses. Journal of Investigative Dermatology Symposium Proceedings, 4: 35-40, 1999.

Hill HZ, Li W, Xin P, Mitchell DL. Melanin: a two edged sword? Pigment Cell \& Melanoma Research, 10: 158-161, 1997.

lida Y, Oh KB, Saito M, Matsuoka H, Kurata H. In vitro synergism between nyasol, an active compound isolated from Anemarrhena asphodeloides, and azole agents against Candida albicans. Planta Medica, 66: 435-438, 2000.

Imokawa G, Kobayashi T, Miyagishi M, Higashi K, Yada Y. The role of endothelin-1 in epidermal hyperpigmentation and signaling mechanisms of mitogenesis and melanogenesis. Pigment Cell \& Melanoma Research, 10: 218-228, 1997.

Kang MC, Lee JY, Lee JA, Han JH, Kim BS, Kim GO. Antioxidant effects and melanin inhibitory effect of natural Pimpinella komarovii extracts in Jeju island. Korean Society for Biotechnology and Bioengineering Journal, 23: 77-82, 2008.

Ministry of Food and Drug Safety. Guidelines for evaluating the functional cosmetics (I). 2003.

Miura T, Ichiki H, Iwamoto N, Kato M, Kubo M, Sasaki H, Okada M, Ishida T, Seino Y, Tanigawa K. Antidiabetic activity of the rhizoma of Anemarrhena asphodeloides and active components, mangiferin and its glucoside. Biological and Pharmaceutical Bulletin, 24: 1009-1011, 2001.

Mosmann T. Rapid colorimetric assay for cellular growth and survival: application to proliferation and cytotoxicity assays. Journal of Immunological Methods, 65: 55-63, 1983.

Park HJ, Lee JY, Moon SS, Hwang BK. Isolation and antioomycete activity of nyasol from Anemarrhena asphodeloides rhizomes. Phytochemistry, 64: 997-1001, 2003.

Park JO, Park JO, Joo CG. A study on whitening and antiinflammatory effects of Eriobotrya japonica leaf extracts with different extraction methods. Journal of the Society of Cosmetic Scientists of Korea, 41: 151-157, $2015 a$.

Park YJ, Ku CS, Kim MJ, Lee MK, Kim KO, Ryu HW, Song HH, Kim DY, Oh SR. Cosmetic activities of nyasol from the rhizomes of Anemarrhena asphodeloide. Journal of Applied Biological Chemistry, 58: 31-38, 2015b.

Ryu MJ. Inhibitory effect of Morus alba extracts on tyrosinase activity and melanogenesis in SK-MEL-2 cells. Asian Journal of Beauty and Cosmetology, 9: 19-30, 2011.

Solano F, Briganti S, Picardo M, Ghanem G. Hypopigmenting agents: an updated review on biological, chemical and clinical aspects. Pigment Cell \& Melanoma Research, 19: 550-571, 2006.

Son KH, Lee JM, Lee SH, Park JH, Kang SJ, Chang SY, Lee KS. Isolation and quantitative determination of Anemarsaponin $\mathrm{B}$ from the rhizomes of Anemarrhena asphodeloides Bunge. Korean Journal of Pharmacognosy, 9: 131-135, 1999.

Sy LK, Yan SC, Lok CN, Man RY, Che CM. Timosaponin A-III induces autophagy preceding mitochondria-mediated apoptosis in HeLa cancer cells. Cancer Research, 68: 10229-10237, 2008.

Tang Z, Li G, Yang J, Duan J, Qian D, Guo J, Zhu Z, Song Z. Anemarrhena asphodeloides non-steroidal saponin components alter the pharmacokinetic profile of its steroidal saponins in rat. Molecules, 20: 11777-11792, 2015.

Taylor SC. Skin of color: biology, structure, function, and implications for dermatologic disease. Journal of the American Academy of Dermatology, 46: S41-S62, 2002.

Thody AJ, Graham A. Does alpha-MSH have a role in regulating skin pigmentation in humans? Pigment Cell \& Melanoma Research, 11: 265-274, 1998.

Uyen LD, Nguyen DH, Kim EK. Mechanism of skin pigmentation. Biotechnology and Bioprocess Engineering, 13: 383-395, 2008.

Wang GJ, Lin LC, Chen CF, Cheng JS, Lo YK, Chou KJ, Lee KC, Liu CP, Wu YY, Su W, et al. Effect of timosaponin A-III, from Anemarrhenae asphodeloides Bunge (Liliaceae), on calcium mobilization in vascular endothelial and smooth muscle cells and on vascular tension. Life Sciences, 71: 1081-1090, 2002.

Yagi A, Kanbara T, Morinobu N. Inhibition of mushroomtyrosinase by Aloe extract. Planta Medica, 53: 515-517, 1987. 


\section{국문초록}

\section{멜라닌 생합성 저해를 통한 지모뿌리추출물에서의 새로운 천연 미백소재의 개발}

서수경 ${ }^{1}$ 한성정 ${ }^{1}$ 구창섭 ${ }^{1}$, 김대현 ${ }^{1}$, 류자현 ${ }^{2}$, 백지훈 ${ }^{2}$, 고재숙 $^{2}$ 장동일 ${ }^{1 *}$

${ }^{1}$ (주콧데 화장품과학연구소, 충청남도 천안시, 한국

${ }^{2}$ (주더마프로 피부임상연구센터, 서울, 한국

목적: 본 연구는 지모뿌리추출물에 의한 미백효과를 확인하기 위한 것이다. 방법: 지모뿌리추출물에 의한 tyrosinase 활성 억제 및 $\mathrm{B} 16 \mathrm{~F} 10$ melanoma 세포를 이용하여 멜라닌 생합성을 측정하였으며 지모뿌리추출물 크림을 제조하여 임상연구도 함께 수행하였 다. 결과: Tyrosinase 활성 및 $\alpha$-melanocyte stimulating hormone $(\alpha-\mathrm{MSH})$ 에 의하여 유도되는 멜라닌 생합성이 지모뿌리추출물 에 의하여 농도 의존적으로 저해되는 것을 확인하였다. 특히, $25 \mu \mathrm{g} / \mathrm{mL}$ 의 농도에서 지모뿌리추출물(28.4\%)은 잘 알려진 멜라닌 생 합성 저해제인 알부틴(24.7\%)보다 더 효과적으로 멜라닌 생합성을 저해하였다. 임상연구에서는, 자외선으로 시험자의 피부에 색소 침착을 유도한 후 지모뿌리추출물이 $2 \%$ 함유된 크림 제형을 사용하도록 한 후 8 주 동안 피부 미백 효과를 조사하였다. 시험 결과 에 의하면 과색소침착 정도, 멜라닌 지수, 그리고 피부 밝기가 유의적으로 개선되었다. 결론: 지모뿌리추출물은 피부 미백을 위한 기능성 화장품 소재로서의 높은 가능성을 기대하게 한다.

핵심어: 지모, 티로신 효소, 천연 미백소재, 피부 미백, 멜라닌

본 연구는 산업통상자원부 경제협력권산업육성사업에 의하여 이루어진 것임(과제고유번호 R0003963).

\section{참고문헌}

박정옥, 박진오, 주철규. 추출 방법에 따른 비파엽 추출물의 미백 및 항염활성에 관한 연구. 대한화장품학회지, 41: 151-157, 2015a.

손건호, 이주미, 이승호, 박정일, 강신정, 장승엽, 이경순. 지모(Anemarrhena asphodeloides Bunge)의 근경으로부터 Anemarsaponin B의 분리 및 함량분석. 생약학회지, 9: 131-135, 1999.

식품의약품안전처. 기능성화장품의 유효성평가를 위한 가이드라인 (I). 2003.

유민정. SK-MEL-2에서 상백피 추출물의 Tyrosinase 활성 억제 및 Melanin 생성 억제 효과. 아시안뷰티화장품학술지, 9 : 19-30, 2011. 


\section{中文摘要}

\section{通过抑制黑色素生成从知母根提取物开发新的天然美白原料}

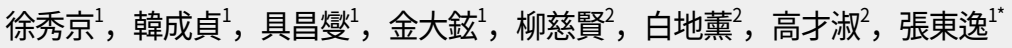

${ }^{1}$ (株)COTDE化妆品科学研究所，忠淸南道天安市，韩国

${ }^{2}$ (株)DERMAPRO皮肤临床科学研究所, 首尔, 韩国

目的: 探索知母根提取物的美白作用。方法: 评估知母根提取物的络氨酸酶抑制活性，研究B16F10 melanoma 细胞中黑 色素的生物合成，并制造含有知母根提取物的乳膏并进行临床试验。结果: 知母根提取物按照浓度依赖性抑制络氨酸酶 活性以及 $\alpha$-melanocyte stimulating hormone（ $\alpha$-MSH）诱导的黑色素生物合成。特别是在 $25 \mu \mathrm{g} / \mathrm{mL}$ 浓度的知母根提取 物 (28.4\%) 比众所周知的黑色素合成抑制剂-熊果苷（24.7\%）更有效地抑制黑色素生物合成。在临床试验中，首先在 受试者的皮肤上，照射紫外线诱导色素沉着后，使用含有 $2 \%$ 知母根提取物的乳膏，并评估8周内皮肤美白效果。试验结 果显示: 色素沉着程度，黑色素指数和皮肤亮度明显改善。结论: 知母根提取物有望作为皮肤美白功能性化妆品原料广 泛使用。

关键词: 知母, 络氨酸酶, 天然美白原料, 皮肤美白, 黑色素 